\title{
Simultaneous mass spectrometry analysis of cisplatin with oligonucleotide-peptide mixtures: implications for the mechanism of action
}

\author{
Farangis Mansouri ${ }^{1,2}$ - Luc Patiny ${ }^{1}$ - Daniel Ortiz ${ }^{1} \cdot$ Laure Menin $^{1}$. Curtis A. Davey ${ }^{3,4} \cdot$ Fakhrossadat Mohammadi $^{2}$ \\ Paul J. Dyson ${ }^{1}$
}

Received: 12 November 2021 / Accepted: 30 December 2021 / Published online: 22 January 2022

(c) The Author(s) 2022

\begin{abstract}
Although genomic DNA is the primary target of anticancer platinum-based drugs, interactions with proteins also play a significant role in their overall activity. In this study, competitive binding of cisplatin with an oligonucleotide and two peptides corresponding to segments of $\mathrm{H} 2 \mathrm{~A}$ and $\mathrm{H} 2 \mathrm{~B}$ histone proteins was investigated by mass spectrometry. Following the determination of the cisplatin binding sites on the oligonucleotide and peptides by tandem mass spectrometry, competitive binding was studied and transfer of platinum fragments from the platinated peptides to the oligonucleotide explored. In conjunction with previous studies on the nucleosome, the results suggest that all four of the abundant histone proteins serve as a platinum drug reservoir in the cell nucleus, providing an adduct pool that can be ultimately transferred to the DNA.
\end{abstract}

\section{Graphical abstract}

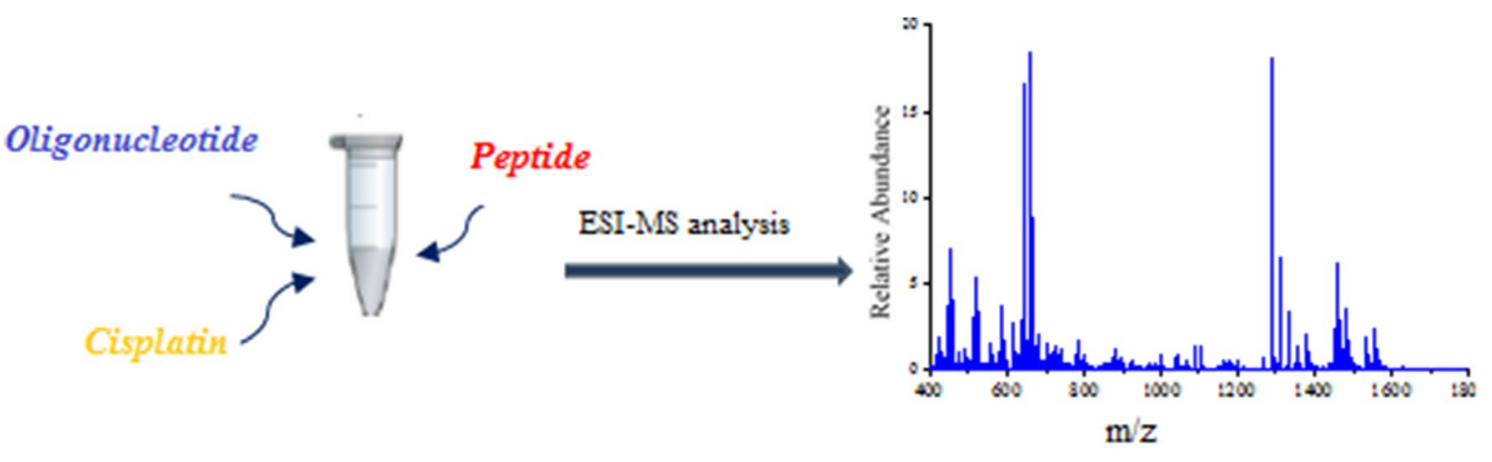

\section{Competition Studies}

Keywords Cisplatin $\cdot$ Mass spectrometry $\cdot$ Drug targets $\cdot$ Histone core particle

Fakhrossadat Mohammadi

fmohammadi@iasbs.ac.ir

Paul J. Dyson

paul.dyson@epfl.ch

1 Institute of Chemical Sciences and Engineering, Swiss

Federal Institute of Technology Lausanne (EPFL),

1015 Lausanne, Switzerland
2 Department of Chemistry Institute for Advanced Studies in Basic Sciences (IASBS), 444 Prof. Sobouti Blvd., Gava Zang, 45137-66731 Zanjan, Iran

3 School of Biological Sciences, Nanyang Technological University, 60 Nanyang Drive, Singapore 637551, Singapore

4 NTU Institute of Structural Biology, Nanyang Technological University, 59 Nanyang Drive, Singapore 636921, Singapore 


\section{Introduction}

Metal complexes exert a wide range of therapeutic effects $[1,2]$ and consequently are extensively used in the diagnosis and treatment of diseases [3]. Among these metal complexes, cis-diamminedichloroplatinum(II), i.e. cisplatin, is the most commonly used drug in cancer chemotherapy [4]. Cisplatin is a prodrug, and once taken up by a cancer cell, it undergoes aquation and the hydrolysed (activated) forms of cisplatin react with DNA to form intra-strand or interstrand cross-links [5, 6]. In addition to DNA binding, cisplatin reacts with many proteins [7-10], with certain cisplatinprotein interactions leading to drug resistance [11]. It has been shown that platinum-modified DNA can react further with chromosomal high mobility group proteins HMG1 and HMG2 affording DNA-Pt-HMG-domain adducts, which prevent nucleotide repair $[12,13]$. Recent reports have revealed that other proteins, such as cytokeratin, elongation factor and histones, bind to DNA after cisplatin treatment [14, 15], affecting nuclear metabolism and chromatin organization [16].

Interestingly, there is a correlation between cytotoxicity and protein-DNA cross-linking [17, 18], and histone proteins are particularly important because they are involved in the formation of the nucleosome as a structural unit of chromatin. Crystallographic studies have shown that platinumbased drugs form extensive adducts with the nucleosome, which appears to be particularly susceptible as sequences which lack preferential targets such as GG or AG sites are platinated, implying that reactivity is enhanced by the histone-bound configuration of DNA or by the proximity of histone proteins $[19,20]$. Indeed, guanine platination is largely controlled by solvent/steric access to the N7 atom, which is moreover modulated by the histone-bound DNA conformation [21].

In the nucleosomal structure, $\mathrm{H} 2 \mathrm{~A}-\mathrm{H} 2 \mathrm{~B}$ dimers located at the outer turn of the nucleosome can be removed and exchanged more easily than the stable $\mathrm{H} 3-\mathrm{H} 4$ core $[24$, 25]. The $\alpha 1-\alpha 2$ helixes and acidic patch region on $\mathrm{H} 2 \mathrm{~A}-$ H2B have a high binding affinity for nuclear factors that influence DNA accessibility, see Fig. 1 [23, 26]. These regions include electronegative (glutamate and aspartate) and also sulphur-donor (methionine) residues that are prone to metal binding [27-29]. Reactivity studies of the model compound $[\mathrm{PtCl}(\mathrm{dien})]^{+}$with peptides and proteins that have sulphur donor atoms show that the resulting $\mathrm{Pt}$-thioether bond may be cleaved with the transfer of the platinum-fragment to the N7 of guanine of an oligonucleotide [30-33]. Moreover, methionine residues of H3 and $\mathrm{H} 4$ were seen to accumulate cisplatin and oxaliplatin adducts in crystallographic studies of platinum drugtreated nucleosome core particle [19,21]. Consequently, platinum-protein adducts may serve as a type of reservoir, storing the platinum adduct and then later releasing it to bind to DNA. Such a mechanism might explain, at least in part, why platinum-based drugs form extensive adducts with the nucleosome.

Herein, we describe the binding of cisplatin to an oligonucleotide model of DNA and two peptides, P1 from the acidic patch region of $\mathrm{H} 2 \mathrm{~A}$ and $\mathrm{P} 2$ from the $\alpha 2$-helix of H2B human histone protein, using electrospray ionisation high-resolution mass spectrometry (ESI-HRMS). The web-based tools Aom ${ }^{2}$ s [34] and $\mathrm{Apm}^{2}$ s [35] were used to
Fig. 1 The crystal structure of the nucleosome and the histone-fold heterodimer. (left) Nucleosome crystal structure based on [[22] PDB ID: 1KX5]. $\mathrm{H} 2 \mathrm{~A}$ is shown in yellow, $\mathrm{H} 2 \mathrm{~B}$ in red, $\mathrm{H} 3$ in blue, $\mathrm{H} 4$ in green and DNA in light grey. Acidic Patch is shown with a dotted circle [23]. (right) Structure of $\mathrm{H} 2 \mathrm{~A} /$ H2B histone-fold heterodimer. Figures were generated using Discovery Studio Visualizer (DSV) 2019
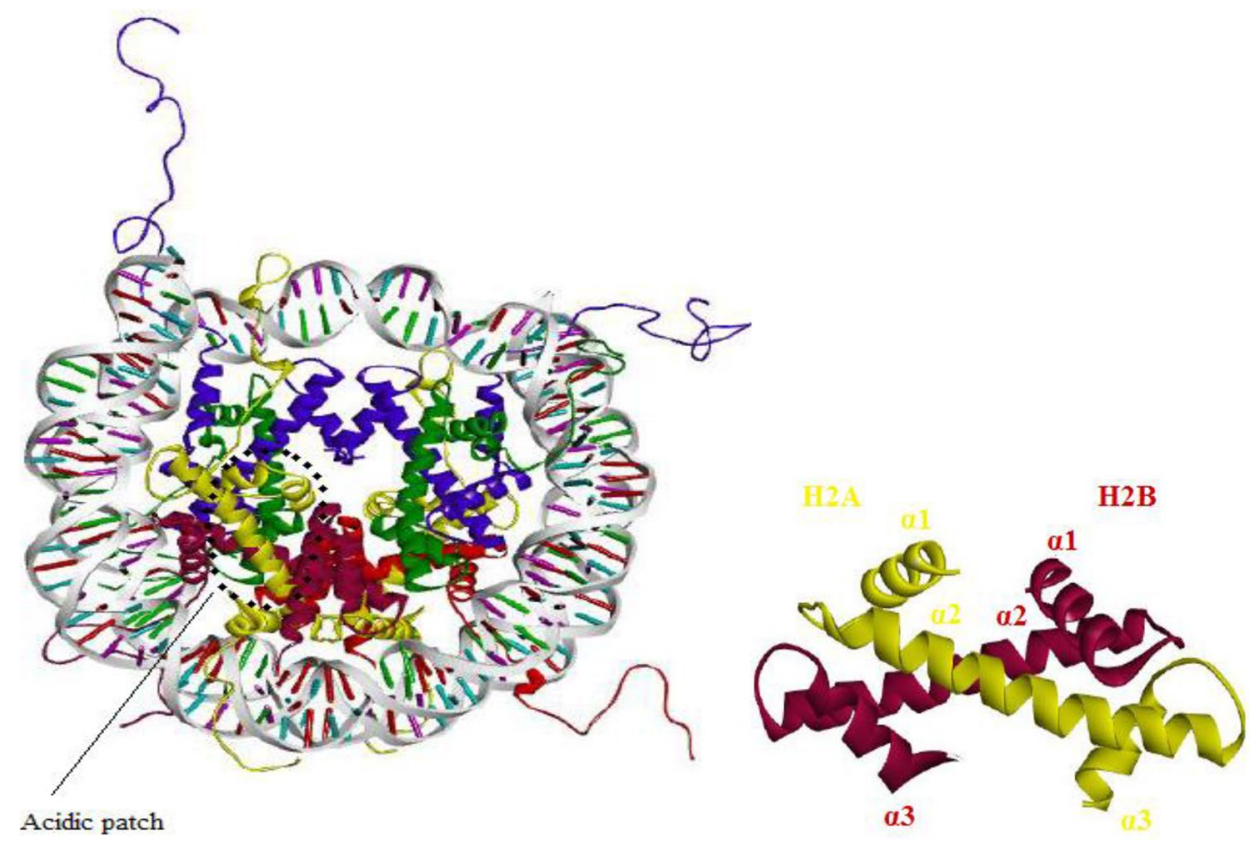
assign and select parent platinated ions for fragmentation. Thousands of theoretical fragments ions generated by the tools were matched with experimental MS/MS fragments and results, returned as free and platinated fragment ions with similarity scores, allowed the preferred binding sites of cisplatin on the oligonucleotide and peptides to be determined. In addition, competitive cisplatin binding between the oligonucleotide and the peptides and the possibility of platinum-adduct transfer from platinated $\mathrm{P}_{2}$ to the oligonucleotide were studied.

\section{Materials and methods}

\section{Reagents}

HPLC-purified double-stranded 13-mer oligonucleotide 5'-GTATTGGCACGTA-3' (S1), 5'-TACGTGCCAATAC-3' (S1c) was obtained as $0.2 \mathrm{mM}$ aqueous solutions from $\mathrm{A} / \mathrm{S}$ Technology (Denmark). Ammonium acetate, ammonium bicarbonate (>99.99\%), HPLC-grade solvents (water, methanol and n-propanol) and cisplatin were purchased from Sigma-Aldrich (Buchs, Switzerland). HPLC-purified, desalted and TFA-absent peptide VLEYLTAEILE $\left(\mathrm{P}_{1}\right)$ and peptide SKAMGIMNSFVNDIFERIAGEASRLAHY $\left(\mathrm{P}_{2}\right)$ were purchased from LifeTein Company (USA).

\section{Oligonucleotide double-stranded binding studies}

Cisplatin and oligonucleotide were incubated in a (3:1) molar ratio in MilliQ water (pH 7) at $37{ }^{\circ} \mathrm{C}$ in the dark for $50 \mathrm{~h}$. After incubation, excess cisplatin was removed using a $3 \mathrm{kDa}$-cutoff Amicon ultra centrifugal filter. Prior to Electrospray ionization High-Resolution Mass Spectrometry analyses (ESI-HRMS), samples were diluted 1:10 with a solution of $1.1 \mathrm{mM}$ ammonium acetate in water-n-propanolmethanol (30:5:65) to obtain a final DNA concentration of $2 \mu \mathrm{M}$. Dilution decreases the exposure of oligonucleotide to high concentrations of organic solvents required for suitable spraying of the samples [36]. To minimize alkali metal cation adducts of oligonucleotide, ammonium acetate was used to exchange $\mathrm{Na}^{+}$and $\mathrm{K}^{+}$with ammonium and samples diluted immediately prior to MS analyses.

\section{Peptide binding studies}

Cisplatin and $\mathrm{P}_{1} / \mathrm{P}_{2}$ were incubated in a $(2: 1)$ molar ratio in MilliQ water ( $\mathrm{pH} 7$ ) containing $0.7 \%$-ammonium bicarbonate $(0.8 \mathrm{mM})$ at $37{ }^{\circ} \mathrm{C}$ in the dark for $48 \mathrm{~h}$. Prior to injection into the mass spectrometer the samples were diluted 1:50 with an aqueous solution of $50 \% \mathrm{MeOH}$ and $1 \% \mathrm{CH}_{3} \mathrm{COOH}$ to obtain a final peptide concentration of $0.4 \mu \mathrm{M}[37,38]$.

\section{Competition studies}

Cisplatin was incubated with the double-stranded oligonucleotide and $\mathrm{P}_{1}$ or $\mathrm{P}_{2}$ in a molar ratio of $(3: 1: 1)$ in MilliQ water (pH 7) at $37^{\circ} \mathrm{C}$ in the dark for $50 \mathrm{~h}$. The ratio equals approximately 1 platinum per 4 base pairs of 13-mer oligonucleotide. To determine the platinated adducts of the oligonucleotide and peptides, each sample was analysed by ESI-MS in both negative and positive ion modes (see Instrumentation below). For negative mode ESI-MS analysis of platinated oligonucleotides, each sample was diluted 1:10 with a $1.1 \mathrm{mM}$ solution of ammonium acetate in water-npropanol-methanol (30:5:65) to obtain a final oligonucleotide concentration of $2 \mu \mathrm{M}$. For positive mode ESI-MS analysis of platinated peptides, an aqueous solution with $50 \%$ $\mathrm{MeOH}$ and $1 \% \mathrm{CH}_{3} \mathrm{COOH}$ was used to dilute the samples to $0.4 \mu \mathrm{M}$ final concentrations of peptides.

\section{Transfer studies}

Cisplatin and $\mathrm{P}_{2}$ were incubated in a molar ratio of (3:1) in MilliQ water (pH 7) at $37{ }^{\circ} \mathrm{C}$ in the dark for $48 \mathrm{~h}$. After incubation, excess cisplatin was removed using $3 \mathrm{kDa}$-cutoff Amicon ultra centrifugal filters and the absence of free cisplatin was checked by ESI-MS (Table S11). The filtered sample was injected into an C18 reverse-phase HPLC column to separate the main cisplatin- $\mathrm{P}_{2}$ adducted from the free $\mathrm{P}_{2}$. The HPLC purified cisplatin- $\mathrm{P}_{2}$ adduct and the oligonucleotide were incubated in a $(1: 1)$ molar ratio in MilliQ water $(\mathrm{pH}$ 7.5 ) at $37{ }^{\circ} \mathrm{C}$ in the dark for $50 \mathrm{~h}$. The samples were analysed by ESI-HRMS in positive and negative ion modes using the same conditions applied in the competition studies [18].

\section{Mass spectrometry instrumentation}

Mass spectra were recorded on an LTQ Orbitrap Elite FTMS instrument (LTQ Orbitrap Elite FTMS, Thermo Scientific, Bremen, Germany). For operation in negative mode, the orbitrap was interfaced with a HESI-II probe in an Ion Max ion Source. The ionization voltage was set at $-1.2 \mathrm{kV}$ and the ion transfer capillary temperature at $120{ }^{\circ} \mathrm{C}$. For operation in positive ion mode, the orbitrap was interfaced with a robotic chip-based nano-ESI source (TriVersa Nanomate, Advion Biosciences, Ithaca, NY, USA). Standard data acquisition and instrument control system were used (Thermo Scientific), and the ion source was controlled by the Chipsoft 8.3.1 software (Advion BioScience). Samples were loaded onto a 96-well plate (Eppendorf, Hamburg, Germany) with an injection volume of $5 \mu \mathrm{l}$. The ionization voltage was set at $+1.4 \mathrm{kV}$, the gas pressure at $0.30 \mathrm{psi}$ and the temperature of ion transfer capillary at $200{ }^{\circ} \mathrm{C}$. For tandem MS data analysis, platinum-containing adducts were fragmented by collision-induced dissociation (CID) in the linear ion trap 
using an isolation window of $8 \mathrm{Da}$, with product ion detected in the Orbitrap with a resolution set to $120 \mathrm{~K}$.

\section{Mass spectrometry data analysis using Aom² and $\mathrm{Apm}^{2} \mathbf{s}$}

High-resolution fragmentation mass spectra of the platinumadducted oligonucleotides were analysed by the automated tool termed Analysis of Oligonucleotide Modifications from Mass Spectra (Aom ${ }^{2} \mathrm{~s}$, https://mstools.epfl.ch/am2s/). This web-based tool written in pure JavaScript is also accessible from the ms.epfl.ch webpage and should be opened through the Google Chrome browser. Aom ${ }^{2} \mathrm{~s}$ calculates theoretical MS and MS/MS ions from oligonucleotide sequences with desired adducts as well as any user-defined fixed and variable modification. Most important parameters to properly use the tool are described in the Aom ${ }^{2} \mathrm{~s}$ web page, as well as in SI and in [34]. For tandem MS experiments, the user specifies a list of allowed fragments from cleavage at the $3^{\prime}$ and $5^{\prime}$ ends including base-losses and neutral losses, as well as internal fragments. The system combines all possible fragments and generates a list of theoretical ions. Subsequently, Aom $^{2} \mathrm{~s}$ automatically matches theoretical isotopic patterns to the experimental isotopically resolved mass spectrum loaded as txt file, yielding a list of matches ranked by $75 \%$ similarity scores. Aom ${ }^{2} \mathrm{~s}$ automatically generates a final graphic representation of the oligonucleotide as a fragment map. All the calculations are performed locally in the browser, therefore with secured data handling. CID fragmentation of platinated peptides was also analyzed by online $\mathrm{Apm}^{2} \mathrm{~s}$ tool (available on https://mstools.epfl.ch/am2s/) which facilitate metal-protein binding studies by identification of all types of internal and terminal fragments. Table $\mathrm{S} 1$ includes general input parameters and data interpretation restrictions applied for data processing using $\mathrm{Aom}^{2} \mathrm{~s}$ and $\mathrm{Apm}^{2} \mathrm{~s}$.

\section{Results and discussion}

Many bioanalytical, biophysical and hyphenated techniques have been used to study metallodrug-biomolecular interactions [39]. Mass spectrometry with different ionization conditions and mass analysers are particularly valuable for determining the binding sites of cisplatin and related compounds to oligonucleotides and proteins [36, 40]. Mass spectrometry data can, however, be difficult to interpret as thousands of peaks are often generated and isotopic patterns frequently overlap. To overcome this challenge we used the web-based tools Aom ${ }^{2}$ s [34] and $\mathrm{Apm}^{2}$ s [35] to automate exhaustive mass spectra matching for the oligonucleotide and peptide binding studies, respectively.

\section{Oligonucleotide binding studies}

ESI-HRMS of the 13-mer double-stranded oligonucleotide, i.e. 5'- GTATTGGCACGTA-3' (S1), 5'-TACGTGCCAATA C-3' (S1c), containing preferential GG and GTG binding sites, incubated with cisplatin, was recorded in negative ion mode. The $\mathrm{Aom}^{2} \mathrm{~S}$ tool was first used to rapidly track platinated adducts of the double-stranded oligonucleotide in the full scan mass spectrum, and 23 platinated ion species with a similarity above $90 \%$ could be assigned (Figure S5). Singly platinated adducts corresponding to $\left[\mathrm{S} 1+\mathrm{Pt}\left(\mathrm{NH}_{3}\right)_{2}-\right.$ $8 \mathrm{H}]^{6-}$ and $\left[\mathrm{S} 1 \mathrm{c}+\mathrm{Pt}\left(\mathrm{NH}_{3}\right)_{2}-8 \mathrm{H}\right]^{6-}$ were observed at $\mathrm{m} / \mathrm{z}$ 701.4438 and 689.6103 , respectively. These adducts were fragmented by CID and, as expected, the main fragments resulting from cleavage of the oligonucleotide were $a / w$ and a-B internal fragments. Nevertheless, all fragment types except $\mathrm{d}-\mathrm{H}_{2} \mathrm{O}$ and $\mathrm{z}-\mathrm{CH}_{2}$ were used to determine the precise cisplatin binding sites on the oligonucleotide. For strand $\mathrm{S} 1$, a total of 100 fragment ions were identified with similarity scores above $75 \%$, among them 22 were platinated. About 39 ions were identified as internal fragments of which 3 were platinated (Tables S2 and S3). Corresponding fragment maps for $\mathrm{S} 1$ are shown Fig. 2, including both unplatinated internal fragments (Fig. 2a) and platinated fragments (Fig. 2b). For S1, the smallest assignable Pt-containing fragment with a similarity $>80 \%$ was a9-B, which contains the expected GG binding site. The Pt-containing fragments a7-B $(\mathrm{G})$ containing the expected GG site were found with a lower similarity score of $78 \%$. Analysis of the fragmentation map of unplatinated internal fragments reveals that a majority of unplatinated internal fragments are more frequently located than GG. The platinated $w 2$ fragment at $\mathrm{m} / z 846.0975$ is isobaric with the platinated internal fragments W12:b3 and w11:b4. For S1c a total of 135 fragment ions were identified with similarity scores above $75 \%$ (Table S4), among them 58 were platinated (Table S5). Once platinated internal fragments were identified out of the 19 internal fragments ions assigned. The corresponding fragment maps for S1c are shown in Figure S6, for both unplatinated internal fragments (Figure S6a) and platinated fragments (Figure S6b). For S1c, the smallest assignable Pt-containing fragments a6 at $\mathrm{m} / \mathrm{z}$ 670.7721 ( 3 charges, $\mathrm{Pt}\left(\mathrm{NH}_{3}\right)_{2}$ ) and a6-B(G) at $m / z 913.1376$ ( 2 charges, $\mathrm{Pt}\left(\mathrm{NH}_{3}\right)_{2}$ ) were assigned with similarities of $95 \%$ and $85 \%$, respectively. They contain the expected GTG binding site reported elsewhere [36]. The fragmentation map of unplatinated internal fragments of S1c (Figure S6a) shows that the vast majority of unplatinated internal fragments are more frequently located after GTG, such as w7:a8-B $(\mathrm{m} / \mathrm{z}$ 466.0422, similarity 94\%), $w 7:$ a10-B $(\mathrm{m} / z$ 1068.1462, similarity 95\%), or w7:a12-B ( $/ 2 / z 842.1213$, similarity $90 \%)$. Around $72 \%$ of platinum-free internal fragments do not include the GTG subsequence. For both strands S1 and S1c, the platinated terminal fragments contain the preferential 
Fig. 2 Fragment maps for the S1 oligonucleotide representing platinated fragment ions after CID fragmentation of $\left[\mathrm{S} 1+\mathrm{Pt}(\mathrm{NH} 3)_{2}-8 \mathrm{H}\right]^{6-}$ at $\mathrm{m} / \mathrm{z}$ 701.4438. a Unplatinated internal fragments. b Platinated fragments. The maps show identified $\mathbf{a}-\mathbf{b}$ in blue, $w-x$ in red and internal fragment ions are displayed as green bars. Modified bases are marked in purple. Fragment types marked in black: average similarity $>90 \%$; fragment types marked in gray fragments: average similarity $<90 \%$ (a)

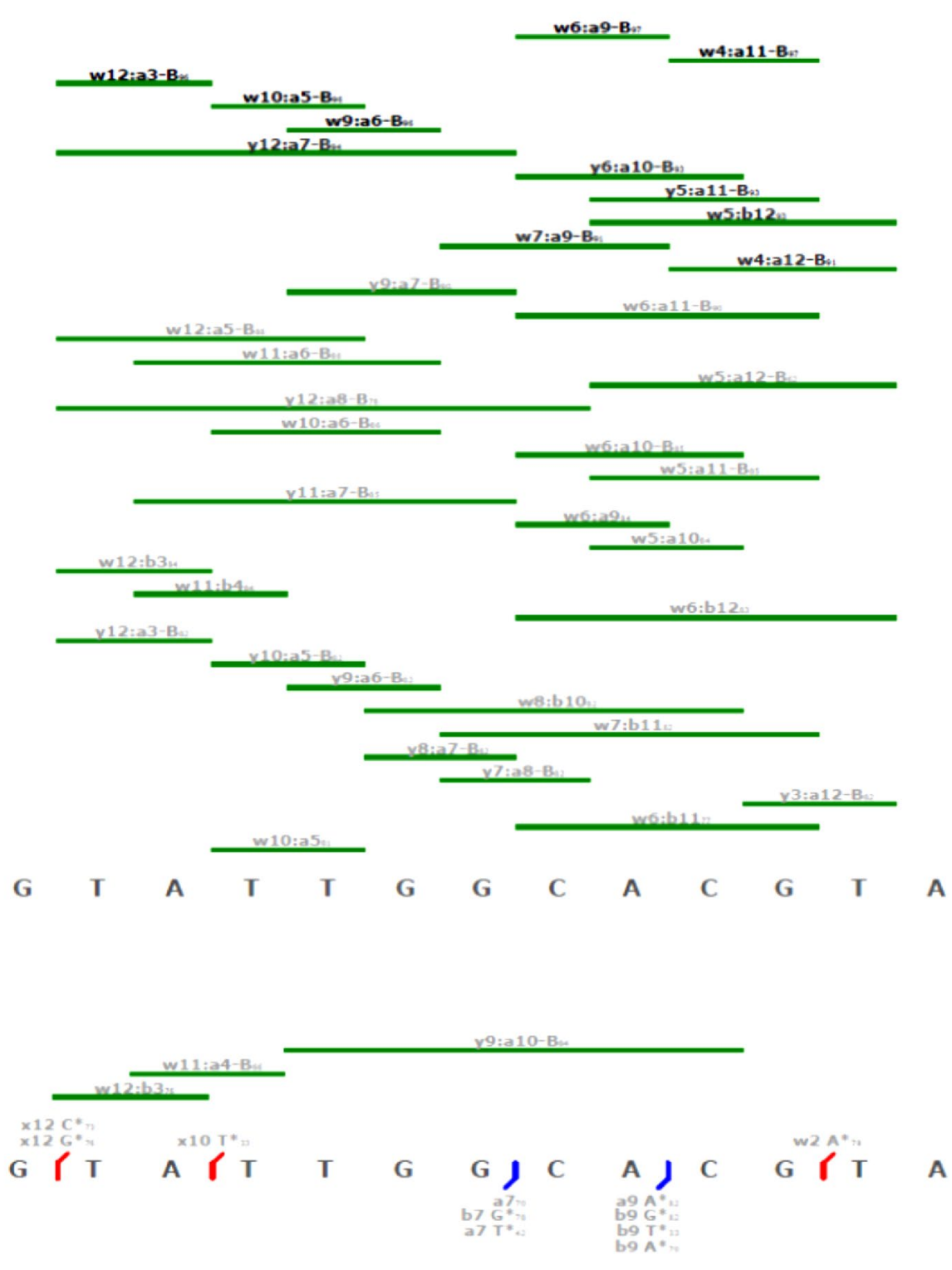

GG and GTG binding sites. Tandem mass experiments were conducted in parallel on unplatinated single-stranded species $[\mathrm{S} 1-5 \mathrm{H}]^{5-}$ at $796.533 \mathrm{~m} / \mathrm{z}$ and $[\mathrm{S} 1 \mathrm{c}-6 \mathrm{H}]^{5-}$ at $782.3331 \mathrm{~m} / \mathrm{z}$ and the list of assigned fragments are displayed in Tables S6 and S7. As shown in Figure S7, internal fragments obtained for $[\mathrm{S} 1-5 \mathrm{H}]^{5-}$ and $[\mathrm{S} 1 \mathrm{c}-6 \mathrm{H}]^{6-}$ all include GG and GTG such as [w10:a9-B-2H] ${ }^{2-}$ at $m / z$ 865.6121 (similarity $89 \%$ ) and [w10:a9-B-3H] ${ }^{3-}$ at $\mathrm{m} / z 576.7425$ (similarity $81 \%$ ) for $\mathrm{S} 1$ and [w10:a9-B-2H] ${ }^{2-}$ at $m / z 858.1162$ (similarity 93\%), [w10:a10-B-3H] ${ }^{2-}$ at $\mathrm{m} / z 1014.6450$ (similarity 96\%), [W10:a6-B-2H] ${ }^{1-}$ at $\mathrm{m} / \mathrm{z} 810.0944$ (similarity 91\%) and [W10:a7-B-2H] ${ }^{1-}$ at $m / z, 1139.1469$ (similarity 96\%) for S1c. Those internal fragments are not detected in the corresponding platinated strands, presumably due to platination of the GG and GTG regions. Platination of the internal part of the strands results in the formation of longer platinated internal fragments which span the entire length, such as y9:a-B10 for S1 and y11:a12-B for S1c.

Percentage values of nucleotide fragments observed for both the Pt-containing and Pt-free samples further confirm preferential binding of cisplatin at the GG and GTG regions due to the higher frequency of platinated fragments in these regions (Fig. 3, Figs. S8 and S9). From Fig. $3 a$ and $b$, it is clear that the 3 ' end participates more frequently in the formation of platinum-free internal fragments and less frequently comprises platinated fragments, i.e. this end is less favorable for metal binding, whereas the 5' end including the GG subsequence has a higher percentage of platinated fragments. Cleavages leading to the formation of the platinated $\mathrm{a} / \mathrm{b} / \mathrm{a}-\mathrm{B} / \mathrm{b}-\mathrm{B}$ fragments are located only on the 3' position of the GTG and GG sequences. This contrasts with the fragmentation pattern 
Fig. 3 a Classification of 5 -end (in blue), $3^{\prime}$-end (in green) and Middle fragments (in brown) of S1 strand of double-stranded oligonucleotide. b Percentage abundance of 5'-end, 3'-end and Middle fragment ions from platinum-free fragmentation and platinated fragment from CID fragmentation of the peak at $\mathrm{m} / \mathrm{z}$ 701.4438 for the $\mathrm{S} 1$ strand (a)

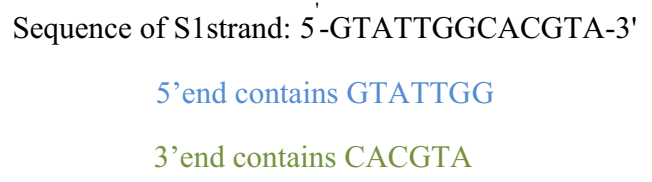

Middle Fragments contains ATTGGCACG

(b)

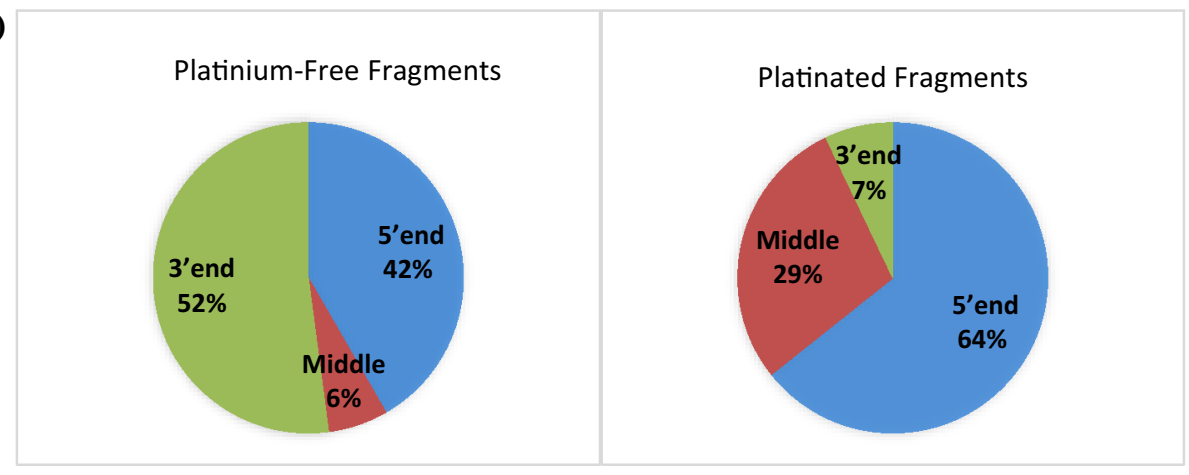

of the free oligonucleotide, and may be attributed to local conformational changes of the strands at the platinated sites (i.e. B-DNA changes to A-DNA) [41]. This conformational change may result in a decrease of cleavages, leading to the formation of platinated internal fragments in the middle part of S1 and S1c strands. Hence, the platination percentage in the middle region is less than that of the 5 ' end (Fig. 3b). In addition, the middle region includes the preferential GG metal-binding site and consequently leads to fewer platinum-free internal fragments (Fig. 3a).

\section{Peptide binding studies}

Two peptides from the outer core of the nucleosome, $\mathrm{P}_{1}$, from the acidic patch region of H2A (VLEYLTAEILE), and $\mathrm{P}_{2}$, the $\alpha_{2}$-helix of H2B (SKAMGIMNSFVNDIFERIAGEASRLAHY), were used for the study as these regions were previously shown to interact with metallodrugs [27]. For $\mathrm{P}_{1}$ incubated with cisplatin, the ion at $\mathrm{m} / \mathrm{z} 760.3546$ corresponding to the $\left[\mathrm{Pt}\left(\mathrm{NH}_{3}\right)_{2}\right]^{2+}$ adduct was selected for CID fragmentation. By analysing platinated and unplatinated $b / y$ type and internal fragments of the peptide $\left[\mathrm{P} 1+\mathrm{Pt}\left(\mathrm{NH}_{3}\right)_{2}\right]^{2+}$ ion (Table S8, Fig. 4), it was found that the platinum-free fragments are mainly y-type e.g. $[\mathrm{y} 9+\mathrm{H}]^{+}$at $m / z 1080.5487$ and fewer b-type are platinum-free e.g. $[\mathrm{b} 5+\mathrm{H}]^{+}$at $\mathrm{m} / \mathrm{z}$ 1032.5617, whereas the platinated fragments are mostly b/atype, e.g. the shortest platinated fragment $\left[\mathrm{b} 2+\mathrm{Pt}\left(\mathrm{NH}_{3}\right)-\mathrm{H}\right]^{+}$ at $m / z$ 423.1354, $\left[\mathrm{a}+\mathrm{Pt}\left(\mathrm{NH}_{3}\right)-\mathrm{H}\right]^{+}$at $m / z 395.1405$ and also some platinated y-type detectable such as [y $4+\mathrm{Pt}\left(\mathrm{NH}_{3}\right)_{2}$ $\mathrm{H}]^{+}$at $m / z$ 730.2734. Most of unplatinated fragments are distributed of the C-terminal part of the peptide, after L5/T6.
According to the abundance of residues in the platinum-free and platinated fragments as shown in the histogram Fig. 5, the N-terminal region has a greater tendency to bind to cisplatin fragments. Hence most of the internal fragments appear to be unplatinated and span the whole peptide sequence except the $\mathrm{N}$-terminal end.

The full mass spectrum of $\mathrm{P}_{2}$ incubated with cisplatin is shown in Figure S10 with the main peaks assigned to platinated species, including both monoadducts, i.e. $\left[\mathrm{P}_{2}+\mathrm{Pt}+3 \mathrm{H}\right]^{5+},\left[\mathrm{P}_{2}+\mathrm{Pt}+2 \mathrm{H}\right]^{4+}$ and $\left[\mathrm{P}_{2}+\mathrm{Pt}\left(\mathrm{NH}_{3}\right)+3 \mathrm{H}\right]^{5+}$ at $\mathrm{m} / \mathrm{z}$ 664.9087, 830.8790 and 668.3100 , respectively, and bis-adducts, i.e. $\left[\mathrm{P}_{2}+2 \mathrm{Pt}\left(\mathrm{NH}_{3}\right)+\mathrm{H}\right]^{5+}$ at $\mathrm{m} / z \quad 710.3051$ and $\left[\mathrm{P}_{2}+2 \mathrm{Pt}\left(\mathrm{NH}_{3}\right)\right]^{4+}$ at $m / z$ 887.6296. $\left[\mathrm{P}_{2}+\mathrm{Pt}+2 \mathrm{H}\right]^{4+}$, indicates that tetradentate coordination with the $\mathrm{P}_{2}$ peptide from $\mathrm{H} 2 \mathrm{~B}$ histone protein can occur. Fragmentation of the $\left[\mathrm{P}_{2}+\mathrm{Pt}+3 \mathrm{H}\right]^{5+}$ ion was performed and the resulting map of platinated fragment ions is displayed in Figure S11 (Table S9 for fragment list), assigned platinated b/y-type fragments with high similarity, i.e. $[\mathrm{y} 25+\mathrm{Pt}+2 \mathrm{H}]^{4+}$ at $\mathrm{m} / \mathrm{z} 759.3395$ and $[\mathrm{b} 17+\mathrm{Pt}+\mathrm{H}]^{3+}$ at $\mathrm{m} / \mathrm{z} 711.9680 \mathrm{cov}-$ ering the region between residues 4 and 17 . This region includes two methionine, aspartate and glutamate residues, which are known to have a high binding affinity to metal ions $[8,35,42]$. Hence, although $\mathrm{P}_{2}$ has a more stable and less flexible structure than $P_{1}$, these residues increase its propensity for binding cisplatin fragments as suggested by the presence of bis-platinated $\mathrm{P}_{2}$ adducts [43]. In particular, two methionine and a histidine residue distinguish $\mathrm{P}_{2}$ from $\mathrm{P}_{1}$, although both have multiple carboxylate residues. MS and crystallography studies indicate that methionine, cysteine, aspartate and histidine side chains in 
Fig. 4 Fragmentation maps of peptide $P_{1}$ after CID fragmentation of the $\left[P_{1}+P \mathrm{t}\left(\mathrm{NH}_{3}\right)_{2}\right]^{2+}$ ion at $m / z$ 760.3546. a Unplatinated fragments. b Platinated fragments. The maps show identified $\mathbf{a} / \mathbf{b}$ type in blue, $\mathrm{y}$ type in red and internal fragment ions displayed as green and orange bars. Fragment types marked in black: average similarity $>90 \%$; fragment types marked in gray fragments: similarity $<90 \%$ (a)

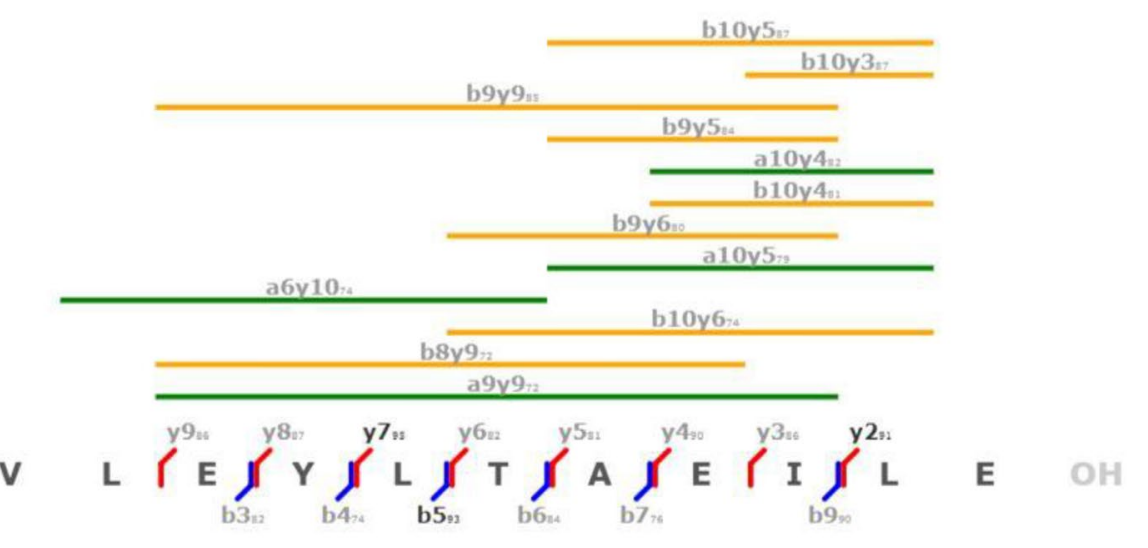

(b)

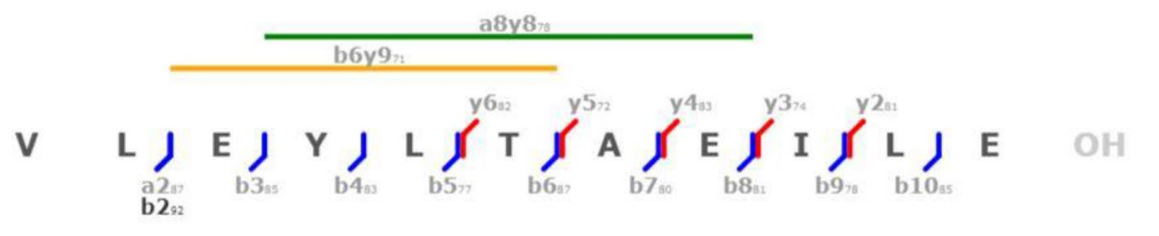

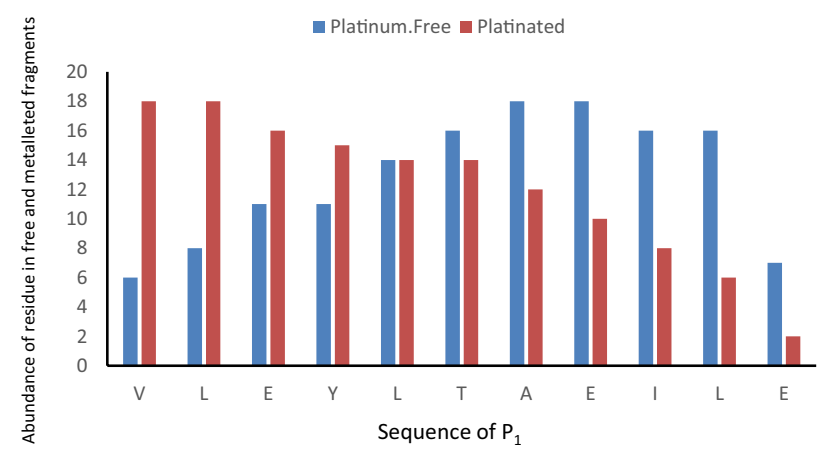

Fig. 5 Location of cisplatin binding site in $P_{1}$ : Histogram showing the occurrence of all assignable amino acids for the unplatinated and platinated fragments resulting from CID fragmentation of the $\left[P_{1}+P \mathrm{t}\left(\mathrm{NH}_{3}\right)_{2}\right]^{2+}$ ion at $m / z, 760.3546$

small proteins preferentially targeted by cisplatin [44-47]. Crystallographic studies of cisplatin-treated nucleosomes reveal pronounced platination of solvent-exposed methionine residues $[19,21]$, suggesting they are the primary sites of adduct formation in $\mathrm{P}_{2}$ and a recent crystallographic study shows that cisplatin-protein adducts retain a certain degree of flexibility and reactivity [48].

\section{Competition and platinum adduct transfer studies}

To establish preferential reactions of cisplatin with DNA and histone proteins in the nucleosome, the double-stranded oligonucleotide and $P_{1}$ or $P_{2}$ were co-incubated with cisplatin in a molar ratio of $(1: 1: 3)$ for up to $50 \mathrm{~h}$. For the co-incubation with $P_{1}$, after $50 \mathrm{~h}$ the highest relative abundance peak in the positive ion spectrum is observed at $\mathrm{m} / \mathrm{z}$ 646.85 corresponding to free $P_{1}$ and platinum adducts are not detected (Figure S12a). In the negative mode spectrum, a low intensity platinated $P_{1}$ ion is detected $(\mathrm{m} / \mathrm{z} .758 .34$, $z=2$ ), but it represents $<1 \%$ of unplatinated $P_{1}$. In contrast, in negative mode unplatinated oligo $\mathrm{S} 1 / \mathrm{S} 1 \mathrm{c}$ was not observed whereas significant amounts of platinated S1 and S1c ions were detected (Figure S12b). Several peaks assignable to $\left[\mathrm{Pt}\left(\mathrm{NH}_{3}\right)_{2}\right]$, bis- $\left[\mathrm{Pt}\left(\mathrm{NH}_{3}\right)_{2}\right]$ and tri- $\left[\mathrm{Pt}\left(\mathrm{NH}_{3}\right)_{2}\right]$ adducts of the oligonucleotide are observed (Table 1 shows the assigned ions).

In a similar co-incubation experiment using $\mathrm{P}_{2}$, only traces of platinated $\mathrm{P}_{2}$ adducts are detected, whereas platinated oligonucleotide ions such as $\left[\mathrm{S} 1+\mathrm{Pt}\left(\mathrm{NH}_{3}\right)_{2}\right.$ $5 \mathrm{H}]^{3-}$ at $m / z 1403.8948$ and $\left(\left[\mathrm{S}_{1} \mathrm{c}+3 \mathrm{Pt}\left(\mathrm{NH}_{3}\right)-9 \mathrm{H}\right]^{3-}\right)$ at $\mathrm{m} / \mathrm{z} 1531.5627$ are abundant after $50 \mathrm{~h}$ of incubation (see Table S10 and Figure S13 in the SI for further details on the assigned ions). These competition experiments indicate that for both peptides studied, cisplatin has a considerably greater binding affinity for the oligonucleotide compared to the peptides, in agreement with published studies [32].

The possibility of transferring platinum adducts from platinated $\mathrm{P}_{2}$ to the oligonucleotide was then investigated. Cisplatin was incubated with $\mathrm{P}_{2}$ and the platinated-peptide was isolated following ultrafiltration and purification by 
Table 1 List of adducts (free and platinated) obtained in negative ion mode using the $\mathrm{Aom}^{2} \mathrm{~s} / \mathrm{Apm}^{2} \mathrm{~s}$ tool for incubation of peptide P1/Oligonucleotide/cisplatin in a ratio of $(1: 1: 3)$ for up to $50 \mathrm{~h}$

\begin{tabular}{lllllllrr}
\hline MF & Ionization & MF Mass & Th m/z & Exp m/z & ppm & Charge & Intensity & Similarity \\
\hline C128H179N55O77P12Pt3(+6) & $(\mathrm{H}+)-9$ & 4674.7577 & 1555.2296 & 1555.2323 & 1.68 & -3 & 1.91 & 0.99 \\
C126H172N52O75P12Pt2(+4) & $(\mathrm{H}+)-7$ & 4374.7391 & 1455.8953 & 1455.8983 & 2.07 & -3 & 4.85 & 0.99 \\
C128H173N53O77P12Pt2(+4) & $(\mathrm{H}+)-7$ & 4445.7398 & 1479.5622 & 1479.5655 & 2.22 & -3 & 2.47 & 0.98 \\
C126H172N52O75P12Pt2(+4) & $(\mathrm{H}+)-8$ & 4374.7391 & 1091.6697 & 1091.6712 & 1.40 & -4 & 1.10 & 0.98 \\
C126H178N54O75P12Pt3(+6) & $(\mathrm{H}+)-9$ & 4603.7570 & 1531.5627 & 1531.5658 & 2.02 & -3 & 1.66 & 0.96 \\
C126H166N50O75P12Pt(+2) & $(\mathrm{H}+)-5$ & 4145.7212 & 1380.2279 & 1380.2304 & 1.78 & -3 & 1.21 & 0.96 \\
C128H173N53O77P12Pt2(+4) & $(\mathrm{H}+)-8$ & 4445.7398 & 1109.4198 & 1109.4209 & 0.90 & -4 & 0.94 & 0.94 \\
C128H179N55O77P12Pt3(+6) & $(\mathrm{H}+)-10$ & 4674.7577 & 1166.1704 & 1166.1719 & 1.28 & -4 & 0.33 & 0.92 \\
C126H178N54O75P12Pt3(+6) & $(\mathrm{H}+)-10$ & 4603.7570 & 1148.4202 & 1148.4232 & 2.63 & -4 & 0.19 & 0.92 \\
C126H166N50O75P12Pt(+2) & $(\mathrm{H}+)-6$ & 4145.7212 & 1034.9191 & 1034.9207 & 1.55 & -4 & 0.32 & 0.90 \\
\hline
\end{tabular}

preparative liquid chromatography (Figure S14). The purity of platinated P2 was confirmed by ESI-MS prior to transfer studies (Table S12). Platinated $\mathrm{P}_{2}$ was then incubated with the oligonucleotide in a 1:1 ratio and the mixture was analysed after 12, 24 and $50 \mathrm{~h}$. The negative ion mass spectra recorded after 12 and $24 \mathrm{~h}$ shows the presence of platinated oligonucleotide such as $[\mathrm{S} 1+\mathrm{Pt}+2 \mathrm{~K}-7 \mathrm{H}]^{3-}$ at $\mathrm{m} / \mathrm{z}$ 1417.8477 (similarity $90 \%$ ) and $[\mathrm{S} 1+\mathrm{Pt}+2 \mathrm{~K}+\mathrm{Na}-8 \mathrm{H}]^{3-}$ at $\mathrm{m} / \mathrm{z}, 1425.1750$ (similarity $80 \%$ ) (Table S13). The negative ion mode spectra are presented in Figures S15 to S17. Although platinated and free $\mathrm{P}_{2}$ were not detected in positive ion mode analyses, the free $\mathrm{P}_{2}$ ion species $\left[\mathrm{P}_{2}-2 \mathrm{H}\right]^{2-}$ was detected at $\mathrm{m} / \mathrm{z}, 1562.2617$ (similarity 96\%) after $24 \mathrm{~h}$ in the negative ion mode. The HPLC purified platinated $\mathrm{P}_{2}$ did not contain free $\mathrm{P}_{2}$, suggesting that migration of platinum fragments from $\mathrm{P}_{2}$ to the oligonucleotide takes place. Hence, binding to the peptide is reversible and the most thermodynamically stable products consist of Pt-oligonucleotide species. These data are in agreement with crystallographic studies of the nucleosome core particle [20] and related transfer studies employing amino acids and nucleobases $[30,49,50]$.

\section{Conclusions}

ESI-MS was used to determine the preferential binding sites of cisplatin adducts on two peptides $\left(\mathrm{P}_{1}\right.$ and $\left.\mathrm{P}_{2}\right)$ from $\mathrm{H} 2 \mathrm{~A}$ and $\mathrm{H} 2 \mathrm{~B}$ histone proteins and an oligonucleotide. The specific search for internal metallated fragment ions was very informative, bringing interesting structural information especially the localisation of drug binding sites. GG and GTG binding sites were found to be most favoured by cisplatin. In addition, methionine, aspartate and glutamate residues were identified as the dominant binding sites in the peptides. Subsequent competition studies between the oligonucleotide and the peptides confirmed that cisplatin reacts preferentially with the oligonucleotide. Moreover, platinum fragments bound to the peptides may dissociate and be transferred to the oligonucleotide. These studies have implications on the mechanism of action of cisplatin and potentially other platinum-based drugs in the treatment of cancer. Indeed, cisplatin may bind first to histone proteins directly, then the bound adducts could transfer to the DNA to form platinated oligonucleotide at the favored GG site. These processes are involved in damaging the DNA and inhibiting cellular proliferation. Our results suggest that the $\mathrm{H} 2 \mathrm{~A}$ and $\mathrm{H} 2 \mathrm{~B}$ histone proteins, in addition to $\mathrm{H} 3$ and $\mathrm{H} 4$, may play role in the mechanism of action of cisplatin and could be implicated in the prevalence of extensive platinum adducts observed in the nucleosome. The more freely exchanging $\mathrm{H} 2 \mathrm{~A} / \mathrm{H} 2 \mathrm{~B}$ dimers may also provide a means for the long-range transfer of platinum drug adducts to distantly related chromatin sites.

Supplementary Information The online version contains supplementary material available at https://doi.org/10.1007/s00775-022-01924-9.

Acknowledgements We thank the Ministry of Science of Iran and EPFL for Financial support. C.A.D was funded by a Singapore Ministry of Education Academic Research Fund Tier 1 Grant (2020-T1-001-128).

Funding Open access funding provided by EPFL Lausanne.

\section{Declarations}

Conflict of interest The authors declare that they have no conflict of interest.

Open Access This article is licensed under a Creative Commons Attribution 4.0 International License, which permits use, sharing, adaptation, distribution and reproduction in any medium or format, as long as you give appropriate credit to the original author(s) and the source, provide a link to the Creative Commons licence, and indicate if changes were made. The images or other third party material in this article are included in the article's Creative Commons licence, unless indicated otherwise in a credit line to the material. If material is not included in the article's Creative Commons licence and your intended use is not 
permitted by statutory regulation or exceeds the permitted use, you will need to obtain permission directly from the copyright holder. To view a copy of this licence, visit http://creativecommons.org/licenses/by/4.0/.

\section{References}

1. Templeton D (2015) Speciation in metal toxicity and metal-based therapeutics. Toxics 3:170-186

2. Boros E, Dyson PJ, Gasser G (2020) Classification of metal-based drugs according to their mechanisms of action. Chem 6:41-60. https://doi.org/10.1016/j.chempr.2019.10.013

3. Mjos KD, Orvig C (2014) Metallodrugs in medicinal inorganic chemistry. Chem Rev 114:4540-4563

4. Florea A-M, Büsselberg D (2011) Cisplatin as an anti-tumor drug: cellular mechanisms of activity, drug resistance and induced side effects. Cancers (Basel) 3:1351-1371

5. Jung Y, Lippard SJ (2007) Direct cellular responses to platinuminduced DNA damage. Chem Rev 107:1387-1407. https://doi.org/ $10.1021 / \mathrm{cr} 068207 \mathrm{j}$

6. Kartalou M, Essigmann JM (2001) Recognition of cisplatin adducts by cellular proteins. Mutat Res 478:1-21. https://doi.org/ 10.1016/s0027-5107(01)00142-7

7. Kasherman Y, Sturup S, Gibson D (2009) Is glutathione the major cellular target of cisplatin? A study of the interactions of cisplatin with cancer cell extracts. J Med Chem 52:4319-4328. https://doi. org/10.1021/jm900138u

8. Peleg-Shulman T, Najajreh Y, Gibson D (2002) Interactions of cisplatin and transplatin with proteins. Comparison of binding kinetics, binding sites and reactivity of the Pt-protein adducts of cisplatin and transplatin towards biological nucleophiles. J Inorg Biochem 91:306-311. https://doi.org/10.1016/s0162-0134(02) 00362-8

9. Sadler PJ (2009) Dalton Transactions themed issue on metal anticancer compounds. Dalton Trans. https://doi.org/10.1039/b9234 98p

10. Peleg-Shulman T, Gibson D (2001) Cisplatin-protein adducts are efficiently removed by glutathione but not by 5'-guanosine monophosphate. J Am Chem Soc 123:3171-3172. https://doi.org/ 10.1021/ja005854y

11. De Luca A, Parker LJ, Ang WH, Rodolfo C, Gabbarini V, Hancock NC, Palone F, Mazzetti AP, Menin L, Morton CJ, Parker MW, Lo Bello M, Dyson PJ (2019) A structure-based mechanism of cisplatin resistance mediated by glutathione transferase P1-1. Proc Natl Acad Sci USA 116:13943-13951. https://doi.org/10. 1073/pnas.1903297116

12. Jamieson ER, Jacobson MP, Barnes CM, Chow CS, Lippard SJ (1999) Structural and kinetic studies of a cisplatin-modified DNA icosamer binding to HMG1 domain B. J Biol Chem 274:12346-12354

13. Brabec V, Hrabina O, Kasparkova J (2017) Cytotoxic platinum coordination compounds. DNA binding agents. Coord Chem Rev 351:2-31

14. Zwelling LA, Anderson T, Kohn KW (1979) DNA-protein and DNA interstrand cross-linking by cis- and trans-platinum(II) diamminedichloride in L1210 mouse leukemia cells and relation to cytotoxicity. Cancer Res 39:365-369

15. Ming X, Groehler A IV, Michaelson-Richie ED, Villalta PW, Campbell C, Tretyakova NY (2017) Mass Spectrometry Based Proteomics Study of Cisplatin-Induced DNA-Protein Cross-Linking in Human Fibrosarcoma (HT1080) Cells. Chem Res Toxicol 30:980-995
16. Woźniak K, Walter Z (2002) Immunospecific protein of $34.5 \mathrm{kDa}$ from DNA-protein cross-links induced by cis-and trans-diamminedichloroplatinum. Cell Biol Int 26:495-503

17. Chválová K, Brabec V, Kašpárková J (2007) Mechanism of the formation of DNA-protein cross-links by antitumor cisplatin. Nucleic Acids Res 35:1812-1821

18. Cheng L, Li C, Xi Z, Wei K, Yuan S, Arnesano F, Natile G, Liu $\mathrm{Y}$ (2019) Cisplatin reacts with histone $\mathrm{H} 1$ and the adduct forms a ternary complex with DNA. Metallomics 11:556-564. https:// doi.org/10.1039/C8MT00358K

19. Wu B, Dröge P, Davey CA (2008) Site selectivity of platinum anticancer therapeutics. Nat Chem Biol 4:110-112

20. Wu B, Davey CA (2008) Platinum drug adduct formation in the nucleosome core alters nucleosome mobility but not positioning. Chem Biol 15:1023-1028

21. Wu B, Davey GE, Nazarov AA, Dyson PJ, Davey CA (2011) Specific DNA structural attributes modulate platinum anticancer drug site selection and cross-link generation. Nucleic Acids Res 39:8200-8212. https://doi.org/10.1093/nar/gkr491

22. Davey CA, Sargent DF, Luger K, Maeder AW, Richmond TJ (2002) Solvent mediated interactions in the structure of the nucleosome core particle at $1.9 \AA$ resolution. J Mol Biol 319:1097-1113

23. Bönisch C, Hake SB (2012) Histone H2A variants in nucleosomes and chromatin: more or less stable? Nucleic Acids Res 40:10719_ 10741. https://doi.org/10.1093/nar/gks865

24. McCauley M, Huo R, Becker N, Holte M, Muthurajan U, Rouzina I, Luger K, Maher L, Israeloff N, Williams M (2018) Single and double box HMGB proteins differentially destabilize nucleosomes. Nucleic Acids Res. https://doi.org/10.1093/nar/gky11 19

25. Corujo D, Buschbeck M (2018) Post-translational modifications of $\mathrm{H} 2 \mathrm{~A}$ histone variants and their role in cancer. Cancers (Basel). https://doi.org/10.3390/cancers10030059

26. Corbeski I, Dolinar K, Wienk H, Boelens R, van Ingen H (2018) DNA repair factor APLF acts as a $\mathrm{H} 2 \mathrm{~A}-\mathrm{H} 2 \mathrm{~B}$ histone chaperone through binding its DNA interaction surface. Nucleic Acids Res 46:7138-7152. https://doi.org/10.1093/nar/gky507

27. Davey GE, Adhireksan Z, Ma Z, Riedel T, Sharma D, Padavattan S, Rhodes D, Ludwig A, Sandin S, Murray BS (2017) Nucleosome acidic patch-targeting binuclear ruthenium compounds induce aberrant chromatin condensation. Nat Commun $8: 1575$

28. Batchelor LK, De Falco L, von Erlach T, Sharma D, Adhireksan Z, Roethlisberger U, Davey CA, Dyson PJ (2019) Crosslinking allosteric sites on the nucleosome. Angew Chemie Int Ed 58:15660-15664. https://doi.org/10.1002/anie.201906423

29. Mohideen K, Muhammad R, Davey CA (2010) Perturbations in nucleosome structure from heavy metal association. Nucleic Acids Res 38:6301-6311

30. Reedijk J (1999) Why does cisplatin reach guanine-N7 with competing S-donor ligands available in the cell? Chem Rev 99:2499-2510

31. Teuben J-M, Reedijk J (2000) Reaction of DNA oligonucleotides with $[\mathrm{Pt}$ (dien) GSMe $] 2+(\mathrm{GSMe}=\mathrm{S}$-methylated glutathione $)$ and cis-[Pt (NH 3) 2 (GSMe) 2] 2+: evidence of oligonucleotide platination via sulfur-coordinated platinum intermediates. JBIC J Biol Inorg Chem 5:463-468

32. Cubo L, Groessl M, Dyson PJ, Quiroga AG, Navarro-Ranninger C, Casini A (2010) Proteins as possible targets for cytotoxic transplatinum(II) complexes with aliphatic amine ligands: Further exceptions to the DNA paradigm. ChemMedChem 5:1335-1343. https://doi.org/10.1002/cmdc.201000104

33. Wang And X, Guo Z (2007) The role of sulfur in platinum anticancer chemotherapy. Anticancer Agents Med Chem 7:19-34. https:// doi.org/10.2174/187152007779314062 
34. Ortiz D, Gasilova N, Sepulveda F, Patiny L, Dyson PJ, Menin L (2020) Aom2S: a new web-based application for DNA/RNA tandem mass spectrometry data interpretation. Rapid Commun Mass Spectrom 34:e8927. https://doi.org/10.1002/rcm.8927

35. Lee RFS, Menin L, Patiny L, Ortiz D, Dyson PJ (2017) Versatile tool for the analysis of metal-protein interactions reveals the promiscuity of metallodrug-protein interactions. Anal Chem 89:11985-11989

36. Egger AE, Hartinger CG, Ben Hamidane H, Tsybin YO, Keppler BK, Dyson PJ (2008) High resolution mass spectrometry for studying the interactions of cisplatin with oligonucleotides. Inorg Chem 47:10626-10633

37. Li H, Zhao Y, Phillips HIA, Qi Y, Lin T-Y, Sadler PJ, O'Connor PB (2011) Mass spectrometry evidence for cisplatin as a protein cross-linking reagent. Anal Chem 83:5369-5376

38. Li H, Snelling JR, Barrow MP, Scrivens JH, Sadler PJ, O'Connor PB (2014) Mass spectrometric strategies to improve the identification of $\mathrm{Pt}(\mathrm{II})$-modification sites on peptides and proteins. J Am Soc Mass Spectrom 25:1217-1227. https://doi.org/10.1007/ s13361-014-0877-0

39. Groessl M, Dyson PJ (2011) Bioanalytical and biophysical techniques for the elucidation of the mode of action of metal-based drugs. Curr Top Med Chem 11:2632-2646. https://doi.org/10. 2174/156802611798040705

40. Allardyce CS, Dyson PJ, Coffey J, Johnson N (2002) Determination of drug binding sites to proteins by electrospray ionisation mass spectrometry: the interaction of cisplatin with transferrin. Rapid Commun Mass Spectrom 16:933-935. https://doi.org/10. $1002 / \mathrm{rcm} .662$

41. Todd RC, Lippard SJ (2010) Consequences of cisplatin binding on nucleosome structure and dynamics. Chem Biol 17:1334-1343. https://doi.org/10.1016/j.chembiol.2010.10.018

42. Bal W, Lukszo J, Bialkowski K, Kasprzak KS (1998) Interactions of nickel(II) with histones: interactions of nickel(II) with $\mathrm{CH}_{3} \mathrm{CO}-\mathrm{Th}$-Glu-Ser-His-His-Lys- $\mathrm{NH}_{2}$, a peptide modeling the potential metal binding site in the "C-Tail" region of histone $\mathrm{H} 2 \mathrm{~A}$. Chem Res Toxicol 11:1014-1023. https://doi.org/10.1021/tx980 $051 \mathrm{y}$
43. Li H, Wells SA, Jimenez-Roldan JE, Romer RA, Zhao Y, Sadler PJ, O'Connor PB (2012) Protein flexibility is key to cisplatin crosslinking in calmodulin. Protein Sci 21:1269-1279. https://doi. org/10.1002/pro.2111

44. Messori L, Merlino A (2017) Protein metalation by metal-based drugs: X-ray crystallography and mass spectrometry studies. Chem Commun 53:11622-11633. https://doi.org/10.1039/C7CC0 6442J

45. Tolbatov I, Marzo T, Cirri D, Gabbiani C, Coletti C, Marrone A, Paciotti R, Messori L, Re N (2020) Reactions of cisplatin and cis-[PtI(2)(NH(3))(2)] with molecular models of relevant protein sidechains: a comparative analysis. J Inorg Biochem 209:111096. https://doi.org/10.1016/j.jinorgbio.2020.111096

46. Ferraro G, Messori L, Merlino A (2015) The X-ray structure of the primary adducts formed in the reaction between cisplatin and cytochrome c. Chem Commun 51:2559-2561. https://doi.org/10. 1039/C4CC09056J

47. Messori L, Merlino A (2016) Review. Coord Chem Rev 315:6789. https://doi.org/10.1016/j.ccr.2016.01.010

48. Merlino A (2021) Recent advances in protein metalation: structural studies. Chem Commun 57:1295-1307. https://doi.org/10. 1039/D0CC08053E

49. van Boom SSGE, Reedijk J (1993) Unprecedented migration of $[\mathrm{Pt}($ dien $)] 2+($ dien $=1,5$-diamino-3-azapentane $)$ from sulfur to guanosine-N7 in $S$-guanosyl-L-homocysteine (sgh). J Chem Soc Chem Commun. https://doi.org/10.1039/C39930001397

50. Chen Y, Guo Z, Sadler PJ (1999) 195Pt-and 15N-NMR spectroscopic studies of cisplatin reactions with biomolecules. Cisplatin Chem Biochem Lead Anticancer Drug. https://doi.org/10.1002/ 9783906390420.ch11

Publisher's Note Springer Nature remains neutral with regard to jurisdictional claims in published maps and institutional affiliations. 